\title{
The Studies Of Leaf Extract Ficus Lyrata Warb On Antimicrobial Activities
}

\author{
Dwi Wahyudha Wira ${ }^{1}$, Efri Mardawati ${ }^{2}$, Mohammad Djali $^{2}$, and Roostita L. Balia ${ }^{1}$ \\ ${ }^{1}$ Study Programme of Veterinary Medicine, Faculty of Medicine \\ Universitas Padjadjaran, Km 21 Jatinangor, 45363, Indonesia \\ ${ }^{2}$ Study Programme of Food Technology, Faculty of Agroindustrial Technology \\ Universitas Padjadjaran, Km 21 Jatinangor, 45363, Indonesia \\ Corresponding Author: dwi.wahyudha@unpad.ac.id
}

\begin{abstract}
The extract of leaf Ficus lyrata Warb has potential as antimicrobial agents, because it contains bioactive components such as polyphenols, tannin and triterpenoid that can inhibit the growth of microbials. The maceration extraction method was used in this study using water as solvent agents, to extract secunder metabolit. The aim of reaserch is to compare the antimicrobial activity between fresh and encapsulation leaf extract. The activity were tested to 2 of bacterias, i.e.; Eschericia coli, dan Bacillus Subtilis. Experimental design of descriptive analysis was used in this research. The results indicated that formation of inhibited zone in the tested media which proved by KirbyBauer testing method are different between fresh and encapsulation leaf extract. Antimicrobial effectiveness of Fresh extract of $F$. lyrata Warb leaf of Bacillus Subtilis is $6.66 \mathrm{~mm}$ and Escherichia Coli is 4.33, on the other hand for encapsulated extract of Bacillus Subtilis is 2,03 mm and Escherichia Coli 3,44 mm. This extract has a potential as natural antimicrobials agent for animals
\end{abstract}

Keywords: antimicrobial activity, bioactive, encapsulation, extraction and Ficus lyrata Warb.

\section{INTRODUCTION}

Ficus constitutes one of the largest generation of medicinal plants with about 750 species ${ }^{1)}$. In Indonesia, the most important species of Ficus are F. lyrata warb, F. elastica and Ficus carica. Various parts of the plant like bark, leaves, stem, fruits, seeds, and fruit are medicinally important ${ }^{1)}$. Ficus usually grows in subtropis and tropical climate areas. Fruits of ficus trees are widely used in fresh or dried form. They are an excellent source of minerals, vitamins, amino acids, crude fibers as well as phenolic compounds ${ }^{1}$. This natural material extracted on the skin of the roots and stems to produce antimicrobial $^{2}$. Compounds contained in the root bark and stems are flavonoids, alkaloids, tannins, phenolic compounds and terpenoids compounds that can inhibit the growth of pathogenic bacteria. The fruit extract of Ficus sycomorous L, Ficus benjamina, Ficus bengalensis L and Ficus religiosa showed antibacterial and antitumor activity ${ }^{3)}$. The extract of $F$. lyrata Warb leaf could showed antimicrobial. The usage of Ficus lyrata leaf extract is not optimal because it has several drawbacks such as high water content, short shelf life and hard handling, thus must be encapsulated. In the encapsulation process required a coating material, one of them is maltodextrin and a drying machine, where that is most often used is the vacuum drying. Encaptulation process of leaf extract would be effect to the antimicrobial activity.

The aim of this study are to determine these compound of phytochemical Ficus lyrata leaf extract and to evaluated of antimicrobial activity Ficus lyrata leaf extract and encapsulated. 


\section{MATERIAL AND METHODS}

\subsection{Raw materials}

\section{Plant Collection}

Fresh leafs of $F$. lyrata or plant parts were collected randomly from Padjadjaran University, Indonesia. Fresh leaf was washed under running tap water, air dried and then grinded to fine powder and stored in airtight bottles.

\subsection{Crude Extraction}

$200 \mathrm{~g}$ of dried powder was extracted in $1600 \mathrm{~mL}$ distilled water for $48 \mathrm{~h}$ at room temperature $^{1)}$. Extraction was conducted in sealed flasks, and then it was filtered through vacuum filtered. The supernatant was collected. It was then rotavaped to result the concentration of extract up to $50 \%$ at $4{ }^{\circ} \mathrm{C}$. All experiments were performed in duplicate to check the reproducibility.

\subsection{Encapsulated}

The extract was mixed with $5 \%$ of maltodextrin and then dried at a temperature of $60^{\circ} \mathrm{C}$ in the vacuum drying. It later grinded to fine powder and sifted through 80 mesh.

\subsection{Analysis}

\section{Phytochemical screening Analysis}

The extracts were screened for phytochemicals like alkaloids, flavanoids, phytosterols, triterpenoids, phenolic compounds and tannins, following the procedure of Harborne ${ }^{3)}$.

\section{Antibacterial activity}

Antibacterial activity of leaf extracts and encapsulated were evaluated by disc diffusion method Kirby Bauer ${ }^{4)}$. The bacteria used in the study include Eschericia coli, dan Bacillus subtilis were obtained from Pharmacy Faculty, Padjadjaran University, Indonesia. The bacterial isolates were first subcultured in a nutrient broth and incubated at $37^{\circ} \mathrm{C}$ for $36 \mathrm{~h}$. Muller-Hinton agar medium was loaded into petridisc, stored until freezing and then inoculated tested bacterial to medium. The diameter of the zone of inhibition was measured in $\mathrm{mm}$. The experiment was repeated in triplicates and the average values were calculated.

\section{RESULTS AND DISCUSSION}

\subsection{Phytochemical screening}

Phytochemical compound screening of $F$. lyrata leaf extracts was conducted using qualitative method including flavanoids, phytosterols, phenolic compounds and tannins from the dried leaf. Phytochemicals such as alkaloids, triterpenoids, and saponin were found to be absent in the extracts. The observed results the value of phytochemical screening were presented in Table 1. 
Table 1 Phytochemical screening the various extracts

\begin{tabular}{lc}
\hline Phytochemical compound & result \\
\hline Phenolic & + \\
\hline Flavonoid & + \\
\hline Alkaloid & - \\
\hline Triterpenoid & - \\
\hline Saponin & - \\
\hline Tannin & + \\
\hline
\end{tabular}

Table 2. Phytochemical compound of extracts

\begin{tabular}{lc}
\hline Phytochemical compound & $\begin{array}{c}\text { Value } \\
(\mathrm{mg} / \mathrm{g})\end{array}$ \\
\hline Phenolic & 1.67 \\
\hline Flavonoid & 1.22 \\
\hline Tannin & 0.95 \\
\hline
\end{tabular}

Note : (+) : Present, (-): Absent

Many of active compound like phenolic compounds in plants comprise a comparatively large class of secondary metabolites with varies potential bioactivities, such as antibacterial and antiinflammatory ${ }^{7,8}$. The amounts of total bioacative compounds in the water extract was huge. It is generally known that water exert a better influence on the extractability of phenolic compounds. The amounts of extracted phenolic compounds obtained in this study were as follows: total phenols of $1.67 \mathrm{mg} / \mathrm{g}$, total flavonoids $1.22 \mathrm{mg} / \mathrm{g}$ and total tannins $0.95 \mathrm{mg} / \mathrm{g}$ as shown in Table 2 .

\subsection{Antibacterial activity}

In the evaluation of antibacterial activity of the Ficus lyrata leaf extract and encapsulated, zone of inhibition was observed in the extracts of water. Microbial growth was determined by measuring the diameter of zone of inhibition. For each bacterial strain, controls were maintained in which pure solvents were used instead of the extract and encapsulated. The antibacterial activity of aqueous extracts against of 2 bacteria are shown in Figure 1

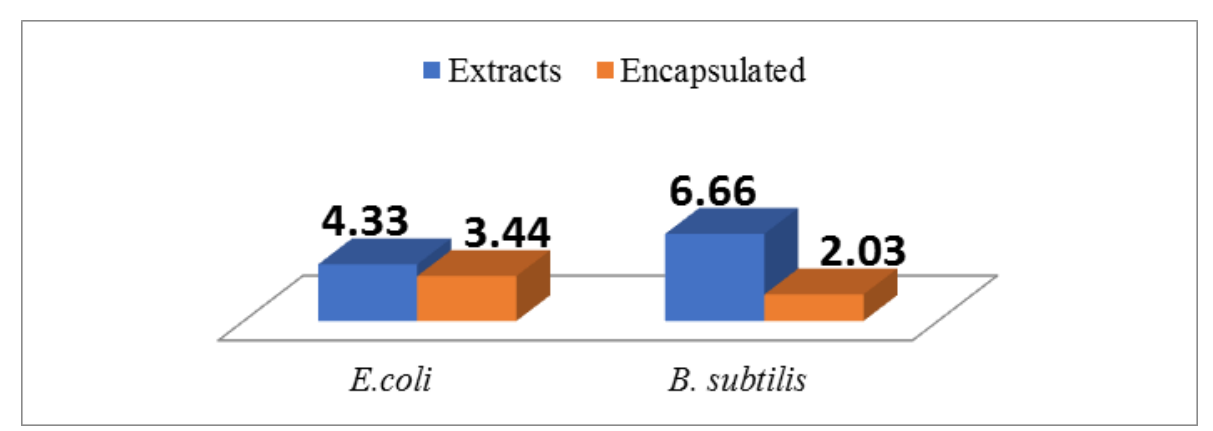

FIGURE 1. Antimicrobial Activity of Ficus lyrata Leaf Exctracts and Encapsulated (inhibition zone in $\mathrm{mm}$ )

The figure 1 showed that the antimicrobial activity decreased after encapsulation. The decline is caused by the encapsulation process which uses a vacuum oven Encapsulation process may reduce bioactive components contained in extracts of leaves of the Ficus lyrata so it can reduce the antimicrobial activity of the leaf extract powderor encapsulated. This is due to the heat treatment process such as drying, concentration and encapsulation of bioactive components that can be reduced, one of which is a phenolic compound. According Vatai et al. (2009) which is stated by Masduqi ${ }^{5)}$ states that the phenolic compounds are very sensitive, unstable and highly susceptible to degradation where main factor are the temperature, oxygen and light. The heat treatment can reduce the content of phenolic compounds may even cause damage to most of the phenolic 
compounds may be caused by chemical changes, decomposition of phenol or phenol-protein complex formation due to temperature and pressure. By decreasing the content of phenolic compounds during drying, the antimicrobial activity of leaf encapsulated generated will decrease as well.

A decrease in antimicrobial activity due to the heat treatment is in line with research Sarjono and Mulyani $(2007)^{6)}$ on the testing of the antimicrobial activity of the rhizome white meeting where the treatment of the sample by heating the autoclave clear zone is smaller than without the autoclave and the effect of reducing antibacterial activity rhizome of ginger and white so can be concluded that the temperature high will likely reduce the antibacterial activity of the rhizome white meeting.

\section{CONCLUSION}

This research showed that extracts of $F$. Lyrata Warb leaf could use as antimicrobial and The phytochemical screening resulted the water leaf extract presence of secondary metabolites like flavanoids, phenolic and tannin. Antimicrobial activity was observed by disc diffusion method against two bacterial pathogens including, Eschericia coli, dan Bacillus subtilis was decreased after encapsulation.

\section{REFERENCES}

1) Jagathambal, M, K.; Madhavan.; Parvathi.; Karunakaran, G.: Journal of Pharmacy Research 4(12), 4498-4500 (2011)

2) Bidarigh, S, P.; Khoshkholgh, A.; Massiha,; Issazadeh, K,: . Proceeding International Conference on Biotechnology and Environment Management IPCBEE vol 18 (2011)

3) Harbone J B., "Phytochemical methods: A guide to modern techniques of plant analysis", 3rd Edn, Chapman and Hill, London, 1998

4) Capuccino, J.G., N. Sherman., "Microbiology : A Laboratory Manual”, Sixth Edition, Benjamin Cummings, San Fransisco, 2001

5) Masduqi, A.F, M. Izzati, E. Prihastanti. 2014. Efek Metode Pengeringan Terhadap Kandungan Bahan Kimia Dalam Rumput Laut Sargassumpolycystum. Buletin Anatomi dan Fisiologi Volume XXII, Nomor 1.

6) Sarjono, P.R, N.S. Mulyani. 2007. Aktivitas Antibakteri Rimpang Temu Putih (Curcuma mangga Vall). Jurnal Sains \& Matematika (JSM) Vol. 15, No. 2; 89-93. ISSN 0854-0675. 